\title{
INKLUSIVITAS PESANTREN TEBUIRENG: MENATAP GLOBALISASI DENGAN WAJAH TRADISIONALISME
}

Syamsul Ma'arif, Achmad Dardiri, Djoko Suryo

IAIN Walisongo, Universitas Negeri Yogyakarta, Universitas Gadjah Mada syamsulmaarif1974@yahoo.co.id, achmaddardiri@yahoo.com, djoko98@yahoo.com

\begin{abstract}
Abstrak
Penelitian ini bertujuan untuk mendeskripsikan inklusivitas Pesantern Tebuireng dalam menatap globalisasi. Penelitian ini adalah penelitian deskriptif kualitatif. Teknik pengumpulan data adalah teknik observasi, partisipasi, interview dan dokumentasi. Teknik analisis datanya adalah teknik analisis domain. Hasil penelitian menunjukkan Pesantren sebagai sebuah lembaga tertua di Indonesia sesungguhnya memiliki karakter unik dan khas yang berbeda dengan lembaga pendidikan agama Islam. Kelenturan sikap dan ekspresi keagamaan yang cenderung inklusif, sering ditunjukkan oleh komunitas pesantren. Hal ini disebabkan karena pada wataknya pesantren memiliki seperangkat aturan, nilai, dan norma yang membudaya dan bersumber pada alquran dan hadistdi samping bersumber pada kesepakatan para ulama. Begitu juga Pesantren Tebuireng, sebagai salah satu pesantren terkemuka di Indonesia terkenal sangat inklusif, senantiasa berusaha menjawab tuntutan-tuntutan globalisasi dengan senantiasa berpegang pada "tradisionalisme" dan kearifan lokal peninggalan Mbah Hasyim Asy'ari dan para leluhurnya. Terbukti dengan paradigma seperti ini, Tebuireng mampu berselayar di tengah tantangan modernitas tanpa harus tercerabut akar-akar kebudayaanya sendiri. Hal ini dapat dijadikan sebagai modal bagi pesantren dalam mendakwahkan prinsip-prinsip ajaran Islam kepada masyarakat tanpa mengalami benturan dan konflik dengan agama lain maupun kepercayaan lokal di Indonesia.
\end{abstract}

Kata kunci: inklusivitas, globalisasi, tradisionalisme, kearifan lokal, Pesantren Tebuireng

\section{THE INCLUSIVITY OF TEBUIRENG PESANTREN: GAZE THE GLOBALIZATION BY TRADITIONALISM FACE}

Syamsul Ma'arif, Achmad Dardiri, Djoko Suryo

IAIN Walisongo, Yogyakarta State University, Gadjah Mada University syamsulmaarif1974@yahoo.co.id, achmaddardiri@yahoo.com,djoko98@yahoo.com

\section{Abstract}

Pesantren as the oldest institution in Indonesia actually has unique character and different specialty with the others Islamic studies institution. The flexibility of attitude and inclined inclusivity of religion expression are almost showed by pesantren communities. It's caused by based of pesantren which has some rules, values, and norms that be entrenched and stem to AlQur'an and Al-Hadist besides Ulama' agreement as a sources. Either Pesantren Tebuireng, as one of foremost pesantren in Indonesia famed so inclusive, always hold on "traditionalism" and local wisdom which is estate by Mbah Hasyim Asy'ari and the his forefathers. Proved by this paradigm, Tebuireng is able to stay amid the challenges of modernity without having cut off the roots of his own culture, besides able be a modals to them in preaching their Islamic principle to the society without getting collision and conflict with another religion even the others local believer in Indonesia.

Keywords: inclusivity, globalization, traditionalism, local wisdom, Tebuireng Pesantren 


\section{PENDAHULUAN}

Modernisme sejak kelahiranya hingga kini, di samping telah memberi dampak positif bagi perkembangan masyarakat menuju sebuah tatanan masyarakat yang civilized, juga meninggalkan sejumlah warisan yang tidak mudah untuk diatasi. Sebab, akibat nyata bagi modernisme adalah globalisasi yang memunculkan sebuah fenomena budaya dengan trend no-limited dan meningkatnya individualisme. Hal ini membawa sejumlah perubahan masyarakat modern yang lebih memilih gaya hidup bebas daripada harus terikat oleh sebuah moralitas agama. Perubahan-perubahan yang dibawa modernisme itu biasanya berakhir dengan sebuah "malapetaka" atau apa yang oleh Francise Fukuyama (2007, p.6), diistilahkan dengan sebutan The Great Disruption.

Di sisi lain, dunia modern juga membuka batas-batas antarbudaya dan negara yang berarti. Menurut Jan Nederveen Pieterse "Globalization involves more intensive interaction across wider space and in shorter time than before" (Pieterse, 2004, p.8). Parahnya bentuk keterbukaan dan pertemuan antarbudaya seperti ini melahirkan bentuk fragmentasi dan The Clash of Civilization, sebagaimana analisis Samuel Huntington (1993), serta melahirkan kecenderungan masyarakat agama yang fundamentalis, eksklusif, dan militan. Agama tampak diekspresikan oleh kaum fundamentalisme secara vis-a-vis dan berlawanan secara langsung dengan globalisasi. Akhirnya, agama malah menjadi sangat kontraproduktif dengan apa yang diharapkan semestinya, yaitu mampu memberikan kontribusi bagi masyarakat modern dengan memformulasikan etos global dan menunjukkan kearifan-kearifan lokal yang dimiliki setiap agama bagi sebuah perdamaian dan perubahan positif.

Secara de facto, munculnya sejumlah kekerasan berbaju agama di negara Indonesia yang terkenal majemuk ini adalah membuktikan statement tersebut. Semua bentuk kekerasan dengan kedok agama seperti yang terjadi selama ini, mungkin saja akan senantiasa terulang, selama perjumpaan antarpenganut agama masih didominasi sikap saling curiga-mencurigai dan belum mampu melebur pada batas agama, tradisi, dan kebudayaan masing-masing. Sebuah persoalan serius harus segera dicarikan pemecahannya (problem sol- ving). Dalam konteks ini, pendidikan (termasuk pesantren) seharusnya memainkan peran yang sangat penting untuk mampu menyosialisasikan etika global dengan penekanan pada sikap saling menghargai dan mutual understanding dari keanekaragaman budaya dan agama. Salah satu etika global yang perlu dipersiapkan pesantren adalah melahirkan "generasi inklusif".

Tidaklah salah melirik pendidikan pesantren dalam upaya mencari strategi pemecahan terhadap problematika munculnya sejumlah kekerasan beragama dan mengembalikan masyarakat yang bermoral (remoralisasi), menuju masyarakat yang inklusif, cerdas, dan arif lan waskitha. Sebab sudah maklum jika setiap masyarakat lokal mempunyai nilai-nilai khusus atau kearifan lokal yang bersumber dari budaya dan agama masyarakat setempat yang dimilikinya sendiri. Biasanya kearifan lokal tersebut dapat digunakan masyarakat untuk menjaga sistem budaya dan ekologi lingkungan. Pesantren sebagai sebuah komunitas khusus (local specific) juga memiliki kearifan lokal. Apalagi pesantren sebagai tempat mempelajari agama Islam dalam realitas historis juga mampu menampilkan manfaat dan kontribusinya bagi masyarakat umum. Pesantren bagi masyarakat selain dianggap sebagai lembaga pendidikan agama juga diyakini sebagai sumber kearifan lokal yang nyata. Ia sering dijadikan sumber rujukan pengetahuan, kebijaksanaan dan keadilan sosial.

Dari awal sejarah kemunculan pesantren yang dipimpin oleh para kiai masuk pada kelompok ortodoks (untuk membedakan dengan kiai pada kelompok fundamentalisme, reformis modern, dan sekuler) meminjam klasifikasi jenis pesantren yang diwacanakan Manfred Ziemek (1986, p.35). Kebanyakan pesantren jenis ortodoks telah menggunakan strategi dakwah yang bisa dibilang sangat inklusif dan mampu menarik perhatian sebagian besar masyarakat Indonesia. Mendirikan pesantren, dapat dijadikan sebagai sarana dan perjuangan dalam berdakwah dan menanamkan nilai-nilai Islam yang selalu mengedapankan moralitas, menjunjung tinggi harkat-martabat kemanusiaan, dan menghargai keragaman. Pesantren jenis ini, sangat terkenal sebagai lembaga pendidikan agama yang selalu mengajarkan Islam berwajah sejuk dan ramah serta 
penerus dakwah yang dilakukan oleh para Walisongo.

Nilai kearifan lokal pesantren merupakan wujud dari proses interaksi yang panjang antara agama Islam yang diyakini dan budaya kemudian terwujud dalam bentuk adat istiadat, kebiasaan, bahasa, sistem kemasyarakatan, budaya guyub, berupa sikap saling menghormati, menghargai, saling memberi kebebasan, toleransi, jujur, dan sederhana. Pesantren dengan kearifan lokal yang berbentuk sistem nilai dan interaksi sosial yang dimilikinya merupakan ruang yang sarat makna karena terbentuk oleh kekuatan masyarakat pesantren sendiri dan bersumber dari kekuatan agama. Pola interaksi antara agama, budaya, dan kearifan lokal pesantren disajikan pada Gambar 1.

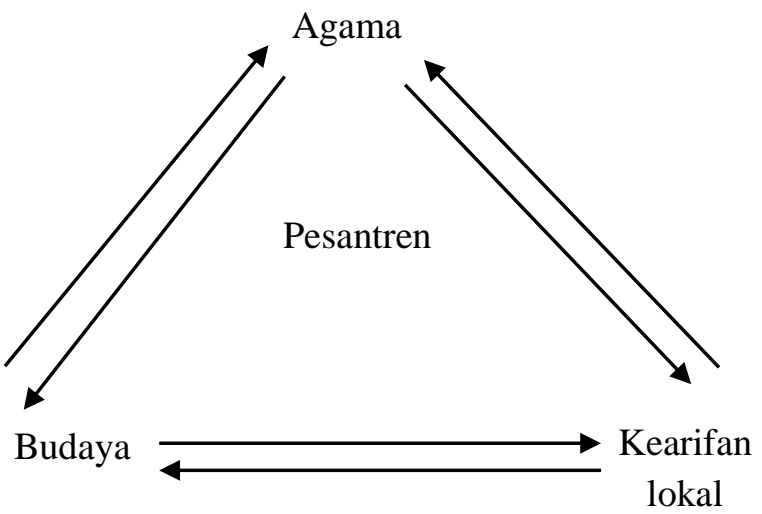

Gambar 1. Pola Interaksi Agama, Budaya \& Kearifan Lokal Pesantren

Salah satu dari sekian banyak pesantren inklusif di Indonesia adalah pesantren Tebuireng. Pesantren yang didirikan oleh KH. Muhammad Hasyim Asy'ari, seorang tokoh dan pendiri NU, seorang kiai yang dilihat dari silsilahnya memiliki garis keturunan dengan Lembupeteng (Brawijaya ke IV) melalui Djoko Tingkir. Dia seorang kiai yang ulet dan cerdas serta memiliki komitmen kuat pada nasionalisme dan selalu membangkitkan semangat umat Islam untuk membangun bangsa. Anaknya yang bernama Abdul Wahid Hasyim, ayahanda Abdurrahman Wahid alias Gus Dur (bapak pluralisme Indonesia) adalah sebagai penerus perjuangan beliau dan juga sangat terkenal sebagai tokoh inklusif dan ikut membidani lahirnya Negara Kesatuan Republik Indonesia. Sejak tahun 2006 sampai sekarang, Pesantren Tebuireng di bawah asuhan adik kandung Gus Dur yakni KH. Sholahuddin Wahid (Gus Sholah) yang terkenal sebagai pejuang dan aktivis HAM serta pernah menjabat sebagai wakil ketua komnas HAM.

Dalam potret sejarah pesantren di Indonesia, Pesantren Tebuireng telah banyak memberi inspirasi bagi pesantren lain di Indonesia dan ikut berkontribusi bagi pembangunan bangsa, terutama sekali dalam hal keberhasilannya menjadi pesantren inklusif, ketika harus melakukan kontak dengan globalisasi. Pesantren Tebuireng, sebagaimana telah ditunjukkan oleh Dhofier melalui penelitianya (1983, p.122), telah membawa sejumlah pesan perubahan serta gagasan baru. Perubahan yang dilakukan Tebuireng dengan begitu dilakukan secara kritis dan tidak membiarkan dirinya mengikuti arus perubahan serta perubahan yang dilakukan masih mendasarkan kepada suatu tradisi yang telah lama mapan dan kuat berakar di masyarakat/Islam tradisional.

\section{METODE PENELITIAN}

Penelitian ini didasarkan pada jenis penelitian kualitatif dengan pendekatan etnografi, sebuah pendekatan yang memerlukan waktu panjang untuk mengobservasi sekelompok masyarakat (pesantren), by sharing their way of life (Travers, 2001, pp.3-4). Tentu saja dalam penelitian ini, peneliti tidak sekedar mendeskripsikan bagaimana kehidupan/budaya pesantren inklusif, tetapi lebih dari itu berusaha menyelediki tingkah lakunya. Berupaya memahami bagaimana pesantren memandang, menjelaskan, dan menggambarkan tata hidup mereka sendiri (Muhadjir, 2011, p.154).

Untuk bisa melakukan hal seperti itu, peneliti sebagaimana pendapat Geertz, harus menggunakan metode interpretif atau disebut dengan thick description. Maksud dan kegunaanya adalah supaya peneliti benar-benar memahami budaya partikular pesantren dan terlibat dalam percakapan dengan orang-orang yang tinggal di dalamnya (Connolly, 2011, p. 136).

Teknik pengumpulan data yang digunakan untuk bisa mengungkap realitas kebudayaan dan kearifan lokal pesantren inklusif di Tebuireng, dilakukan collecting data dengan mendasarkan pada teknik yang disampaikan James P. Spradley dengan alur penelitian maju bertahap (Spradley, 1997, pp.55- 
128). Dalam penelitian ini, dipilih berbagai langkah sebagai berikut: (1). menetapkan seorang informan; (2). mewancarai seorang informan.; dan (3) membuat catatan etnografis. Proses ini kalau digambarkan adalah sebagai berikut:

\begin{tabular}{|c|c|c|}
\hline $\begin{array}{l}\text { penemuan } \\
\text { ethnografis }\end{array}$ & $\begin{array}{l}\text { membuat catatan } \\
\text { etnografis }\end{array}$ & $\begin{array}{l}\text { Deskripsi } \\
\text { etnografis }\end{array}$ \\
\hline
\end{tabular}

Gambar 2. Proses Membuat Catatan Etnografis

Sedangkan teknik pengumpulan data dalam penelitian ini adalah (1) teknik observasi-partisipan; (2) teknik interview; dan (3) teknik dokumentasi.

Supaya memperoleh derajat kepercayaan dan bisa dipertanggungjawabkan secara ilmiah, perlu dilakukan pemeriksaan keabsahan data dengan teknik triangulasi, yaitu teknik pemeriksaan keabsahan data yang memanfaatkan sesuatu yang lain. Bentuk triangulasi yang digunakan dalam penelitian ini, meminjam penjelasan Denzin sebagaimana dikutip Lexy J. Moleong (2007, pp.330332) adalah triangulasi sumber, metode dan teori.

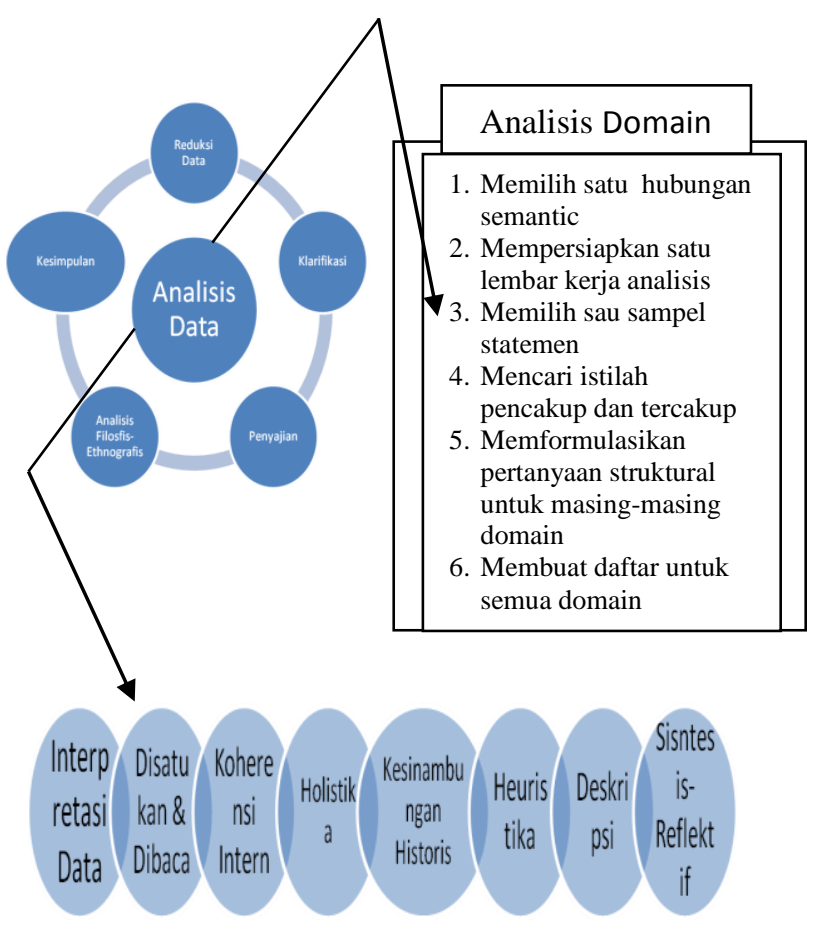

Gambar 3. Tehnik Analisis Penelitian

Analisis data pada penelitian ini dilaksanakan secara simultan/sepanjang proses penelitian berlangsung. Adapun teknik anali- sis data yang digunakan adalah teknik analisis domain. Dengan menggunakan konsep relasional, dapat ditemukan sebagaian besar prinsip-prinsip yang dimiliki Pesantren Tebuireng untuk menyusun simbol-simbol ke dalam domain-domain (Spradley, 1997, pp.139-155).

Dengan bantuan filsafat analitis, dalam analisis data ini peneliti tidak akan membuat proposisi-proposisi, akan tetapi lebih tertarik pada klarifikasi makna yang sebenarnya dari proposisi-proposisi yang dilontarkan oleh informan (Knight, 1982, p.116). Kalau digambarkan teknik analisis penelitian ini terdiri dari beberapa kegiatan yang saling berinteraksi satu sama lain yaitu: reduksi data, klarifikasi, penyajian data, analisis filosofisethnografis, dan penarikan simpulan.

\section{HASIL PENELITIAN DAN PEMBAHASAN}

\section{Letak Geografis}

Pesantren Tebuireng Jombang terletak di daerah Cukir kecamatan Diwek Kabupaten Jombang. Tebuireng adalah sebuah pedukuhan yang berada pada kilometer 8 dari kota Jombang ke arah selatan. Di tempat pedukuhan yang mempunyai luas 25,311 hektar inilah, seorang ulama terkenal bernama lengkap KH. M. Hasyim Asy'ari mendirikan sebuah pesantren pata tanggal 26 Rabiul Awwal $1317 \mathrm{H}$ bertepatan dengan 3 Agustus 1899 M. Disebut pesantren "Tebuireng", karena memang pesantren ini berada di daerah yang memiliki luas area yang cukup luas dan produksi perkebunan tebu yang melimpah, jika dibanding dengan daerah-daerah lain di Kabupaten Jombang. Luas area Kecamatan Diwek adalah $1.333 \mathrm{Ha}$ dan produksi perkebunan tebu pada tahun 2009 sejumlah 1.101.058 ton. Menurut beberapa versi, munculnya nama Tebuireng adalah semenjak berdirinya pabrik gula selatan dusun. Karena hal ini mendorong masyarakat menanam tebu dan kemungkinan yang ditanam berwarna hitam, maka dusun tersebut dinamakan Tebuireng, gabungan dari kata "tebu" dan "ireng". Sementara menurut penuturan almarhum KH. Ishomuddin Hadzik, nama Tebuireng berasal dari kata "kebo ireng", bahasa Jawa yang mempunyai arti kerbau hitam. Tetapi, terdapat juga versi lain bahwa sebutan Tebuireng adalah pemberian dari seorang punggawa kerajaan Majapahit yang masuk Islam dan kemudian 
tinggal di sana (Yasin \& Karyadi (Ed.), 2011. pp. 3-4).

Masyarakat di sekitar Pesantren Tebuireng, sebagaimana penduduk di Indonesia lainya, terdiri dari beragam etnis, agama, dan struktur sosial dengan latarbelakang status ekonomi yang berbeda-beda. Ada sebagian masyarakat yang hidup dalam kecukupan, bahkan kaya dan sebagian yang lain dalam kondisi sangat memprihatinkan. Meskipun begitu, mayoritas penduduk dapat dikatakan, perekonomiannya sudah relatif membaik, lebih-lebih pasca wafatnya Gus Dur, karena desa Cukir mendadak menjadi "kampung wisata" dan banyak dikunjungi para peziarah. Fenomena ini sangat menguntungkan warga sekitar karena mereka dapat membuka lapangan pekerjaan baru. Rumah-rumah sekitar pesantren, terutama menuju makam Gus Dur, kemudian banyak direnovasi menjadi pertokoan, rumah penginapan, membuka WC/toilet umum, mendirikan Pedagang Kaki Lima (PKL) untuk jualan makanan/minuman, kaset dan CD serta buku-buku agama, dan lain sebagainya. Menariknya, suasana saling menolong, menghormati, dan saling mengasihi sangat kental di sekitar pesantren. Lebihlebih, mayoritas masyarakat Cukir berideologi ahlu sunnah waljamaah (aswaja) dan dikelilingi oleh pesantren-pesantren tersohor (diantaranya Pesantren Seblak, Pesantren Cukir, Pesantren Masruriyah, Pesantren Kwaron dan Pesantren Tahfid Al-Dur'an) sehingga membentuk budaya sendiri ala "kampung santri" yang terkenal sangat toleran.

\section{Akar Inklusivisme Pesantren Tebuireng}

Meskipun Pesantren Tebuireng bukan sebagai pesantren tertua di bumi pertiwi, pesantren ini mempunyai berbagai jejak sejarah yang sangat menarik dan andil yang sangat besar bagi pencerdasan serta kemerdekaan bangsa Indonesia. Selain terkenal sebagai "pesantren perjuangan" dan melahirkan pahlawan nasional, Pesantren Tebuireng juga mempunyai andil dalam pengembangan ekonomi dan penguatan civil society (Yasin \& Karyadi (Ed.), 2011. pp.3-4), termasuk membangun karakter dan moral masyarakat, mengintrodusir dan memperkuat wawasan kebangsaan dengan upaya menjadikan masyarakat demokratis dan terbiasa hidup dalam perbedaan.

Dinamika sejarahnya pun telah mencatat sifat "keterbukaan" bagi perubahan dan kehidupan yang lebih baik. Pandangan yang selalu dijadikan pegangan Pesantren Tebuireng adalah al-Muhafadlatu 'ala qadimi al-shalih wa al-akhdzu bi al-jadidi al-ashlah. Dengan konsep ini, Pesantren Tebuireng berpandangan bahwa merespon dan menjemput perubahan adalah sebuah kenicayaan. Karena semua hal yang di dunia ini, dianggap mengalir dan semua mengalami perubahan sesuai dengan jamannya. Pesantren ini cukup terbukti telah menerapkan konsep ini, dengan karakter sangat akomodatif dan adaptif terhadap setiap bentuk "perubahan" demi perbaikan di masa depan. Bentuk keterbukaan Pesantren Tebuireng adalah menumbuhkan sikap lentur/ fleksibel serta tulus ikhlas menerima setiap masukan positif, kontruktif, dan inovatif.

Bahkan seorang pendirinya, meskipun terkenal sebagai kiai jebolan dari sistem pendidikan salaf, kiai Hasyim mempunyai pandangan sangat progresif. Sejak pertama kali mendirikan Pesantren Tebuireng (tepatnya pada tanggal 26 Rabiul Awal 1317 H dan bertepatan dengan tanggal 3 Agustus 1899 M) salah satu orientasi yang ingin direalisasikan adalah ingin menjadikan pesantren sebagai agen perubahan sosial. Kiai Hasyim menganggap pesantren tidak hanya sebagai tempat pendidikan, tetapi juga sarana penting untuk membuat perubahan secara mendasar bagi masyarakat luas. Maka beliau sangat setuju dengan ide-ide pembaharuan di pesantren, seperti memasukkan mata pelajaran umum dan lain sebagainya. Semua itu dilakukanya karena situasi yang menuntut berpikir rasional, inklusif dan berperilaku adaptif sebagai upaya rekontruksi pesantren agar tetap survive dan relevan dengan perkembangan sains-teknologi, penyebaran arus informasi, dan perjumpaan antarbudaya.

Lathiful Khuluq dalam penelitiannya menyimpulkan bahwa watak keterbukaan dan toleran pada pendapat orang lain yang ditunjukkan Kiai Hasyim itulah yang menyebabkan beliau dengan mudah membangun pesantren sendiri, dapat menyerukan persatuan dan kesatuan, serta membangkitkan semangat nasionalisme. Ia juga terbukti dapat menerima metode pengajaran baru yang ditawarkan oleh para kiai dan guru di pesantrennya, meskipun ia sendiri masih menggunakan satu metode pengajaran sebagaimana kebanyakan kiai yang lain (Khuluq, 2000, p.156). 
Selain itu, Kiai Hasyim sebagai Pengasuh Pesantren Tebuireng periode pertama (1899-1947) telah meletakkan dasar-dasar spirit humanisme dan inklusifisme pesantren. Gus Dur, sebelum wafat telah menunjukkan bahwa di Pesantren Tebuireng masih terlihat koleksi Kiai Hasyim yang berupa sejumlah buku yang mencerminkan pandangan humanistik, seperti karya Abul Barakat Abdurrahman bin Nuh bin Ubaidillah bin Abu Said Kamaludin Ibnul Anbari yang berjudul Nuzhat al-Alibba fi Thabaqat al-Udaba' (Wahid, 2007: 131). Kiai Hasyim sendiri mengarang sejumlah kitab, diantaranya yang sangat terkenal dan menjadi salah satu referensi di pesantren yaitu al-Tibyan fi al-Nahyi 'an muqatha'ati al-Arham wa al-Aqarib wa alIkhwan yang berisi tentang pentingnya menjaga tali silaturrahmi (persaudaraan) dan bahayanya memutus tali persaudaraan. Spirit Kiai Hasyim tentang keterbukaan dan perjuangannya menegakkan nilai-nilai agama untuk "kemanusiaan" tersebut kemudian mengilhami dan memercikkan semangat reformasi pada generasi-generasi sesudahnya. Memang nilai-nilai/ajaran-ajaran yang diajarkan Kiai Hasyim telah menjadi semacam budaya dan kearifan lokal yang ditransmisikan dari satu generasi ke generasi selanjutnya sampai pada periode sekarang dan sering disebut sebagai periode revitalisasi di bawah asuhan $\mathrm{KH}$. Solahuddin Wahid (Gus Solah), seorang yang sangat terkenal berwawasan luas, terbuka, egaliter, dan low profile.

\section{Budaya dan Kearifan Lokal Pesantren Tebuireng}

Bila menilik fakta sejarah, sungguh kontribusi Pesantren Tebuireng bagi bangsa Indonesia sungguh amat nyata dan begitu besar, baik pada masa sebelum kemerdekaan maupun sesudahnya. Pada masa pra-kemerdekaan pesantren ini terbukti telah meng-gelorakan semangat antipenjajah dan menanamkan sikap patriotisme kepada para santri/masyarakat untuk merebut kemerdekaan. Sementara pasca-kemerdekaan pun, pesantren ini selalu terdepan dalam membangun kecintaan para santri untuk menjaga dan mencintai negara Indonesia. Melalui pintu pendidikannya, Pesantern Tebuireng telah menginspirasi sekaligus membudayakan para santri dan masyarakat bersifat "inklusif" sebagai salah satu karakter bagi kebangkitan civil society.
Pesantern Tebuireng selalu mendorong bagi masyarakat muslim untuk menyajikan Islam dalam kemasan yang atraktif dan selalu menampilkan wajah Islam yang rahmatan lil'alamin, yang senantiasa menjaga tali persaudaraan demi persatuan dan kesatuan bangsa.

Sikap dan cara pandang/pola keberagamaan yang selalu integral, moderat, dan berwawasan kebangsaan dan kenegaraan seperti itu telah menjadi world view Pesantren Tebuireng dan senantiasa dijaga secara turuntemurun. Adapun yang membentuk tradisi dan sikap keberagamaan yang begitu lentur dan akomodatif terhadap setiap bentuk perubahan demi kemaslahatan ummat, sebagaimana pengamatan dan wawancara mendalam dengan berbagai informan di Pesantren Tebuireng adalah beberapa budaya dan kearifan lokal yang semuanya diakui bersumber dari ajaran-ajaran Kiai Hasyim. Secara garis besar budaya dan kearifan lokal Pesantren Tebuireng adalah sebagai berikut:

\section{Memperkuat Silaturrahim dan Mencairkan Eksklusifisme}

Sudah maklum, jika budaya silaturrahim yang berkembang di pesantren dan bahkan telah menjadi "kebiasaan" pada masyarakat luas di luar pesantren sesungguhnya berasal dari bahasa Arab "shilatun" yang berarti menyambung dan "rahimun" yang berarti keluarga. Melihat peran penting silaturrahim bagi terciptanya persatuan dan kesatuan. Maka dalam rangka merealisasikan konsep ini, Pesantren Tebuireng telah menyelenggarakan beberapa agenda silaturrahim tersebut baik berbentuk halal bihalal yang bersifat internal keluarga pesantren maupun dengan para santri yang disebutnya "reuni".

Semua itu dalam rangka merealisasikan ajaran dari Kiai Hasyim dalam kitab beliau yang sangat terkenal dan ditulis pada $1360 \mathrm{H}$ (73 tahun silam) yaitu; "al-Tibyan $\mathrm{fi}$ al-Nahy 'an Muqatha'ah al-Arham wa alAqarib wa al-Ikhwan (sebuah penjelasan yang menerangkan larangan memutus hubungan famili, kerabat, dan teman). Menurut pernyataan Gus Solah bahwa dialah yang mempelopori dimulainya halal bihalal bani Asy'ari (ayah dari Hadratusn Syekh KH. Hasyim Asy'ari). "Saya sendiri yang mempunyai gagasan untuk mengadakan halal bihalal bani Asy'ari tersebut dan yang hadir 700 orang" 
(wawancara, 3/9/2013). Memperhatikan peran positif silaturrahmi inilah, Gus Solah berkeinginan untuk memperluas maknanya yaitu dari hanya sekedar silaturrahmi pribadi menjadi kerja sama sosial dan bisnis bersekala besar. Sementara Temu Alumni Pesantren Tebuireng sudah dimulai sejak tahun 2006 dan menjadikan Temu Nasional setiap tahun yang diadakan pada hari Sabtu terakhir bulan Syawal (Wahid, 2012. p. 5).

Praktik saling bersilaturrahmi sebagaimana diimplementasikan di Pesanteran Tebuireng mengesankan sebuah hubungan yang benar-benar dibangun atas sebuah kesadaran akan pentingnya "persaudaraan", penghormatan antara kiai/ustad dan santri serta atas nama kemanusiaan. Bahkan Pesantren Tebuireng membuka lebar-lebar pintu silaturrahim dengan masyarakat secara keseluruhan, Sikap seperti ini justru dapat membuahkan hubungan dan kerja sama yang positif dan berskala luas. Beragam tamu dengan latar belakang agama dan budaya pernah berkunjung ke Pesantren Tebuireng baik dari kalangan masyarakat biasa, para politisi, pejabat pemerintahan, maupun seniman. Pernah juga, sebagaimana pengakuan Gus Solah, "para pendeta tinggal beberapa minggu di sini dengan maksud untuk mempelajari ajaran Islam di pesantren" (Wawancara, 3/9/2013).

Mungkin sikap keterbukaan Pesantren Tebuireng seperti itu tiada lain adalah, sebagaimana yang dimaksud dengan penjelasan Gus Solah, sebagai "prasarat" bagi makna silaturrahim agar lebih produktif dan bermanfaat, yaitu dengan cara mengubah pandangan ke dalam masing-masing pesantren menjadi pandangan ke luar dan menyadari adanya potensi yang besar itu. Maka, sikap keterbukaan melalui silaturrahim akan memberikan manfaat dan maslahat serta mampu mencairkan kebekuan yang ada di masyarakat, memperkuat rasa toleransi, dan dapat mempertemukan ragam perbedaan menjadi modal yang efektif demi merealisasikan tujuan bersama. Tetapi sayang, makna dan fungsi silaturrahmi yang besar seperti tersebut pada praktiknya di pesantren menurut Gus Solah (wawancara, 3/9/2013) belum berhasil secara maksimal, karena "sillaturrahmi hanya dimaknai dengan salaman-salaman yang basa-basi dan habis itu tidak ada efeknya". Bahkan Gus Solah menulis secara khusus dalam surat kabar Jawa Pos dengan judul "Sulitnya Mencapai Kata
Sepakat" (Wahid, Juni 2014), intinya beliau menyayangkan budaya silaturrahmi di pesantren belum berhasil dimanfaatkan secara baik. Hal ini ditunjukkan oleh beliau seperti fenomena pilpres, "dari pengalaman yang ada, warga dan tokoh NU serta ulama pesantren selalu terpecah dalam menentukan pilihan". Padahal semestinya dengan kekuatan tradisi silaturrahmi yang dimilikinya, masih menurut penjelasan Gus Solah, lebih memudahkan warga NU dan pesantren untuk bersatu dan berhasil mencapai kata sepakat dalam menghadapi berbagai masalah yang timbul/dihadapi seperti pada kasus pilkada dan pilpres.

\section{Tasamuh dan Membangun Harmoni}

Tasamuh merupakan salah satu ajaran Kiai Hasyim yang senantiasa beliau contohkan kepada para santri semasa beliau masih hidup. Maka wajar jika sampai sekarang, karakter ini sangat ditekankan di Pesantren Tebuireng. Adapun yang dimaksud nilai tasamuh di sini adalah sebuah sikap untuk dapat menghormati dan menghargai perbedaan, baik dalam hal agama, budaya maupun etnis. Lebih jelas, Gus Solah mendefinisikan tasamuh yang ingin diterapkan pada Pesantren Tebuireng adalah "sikap lapang hati, peduli, toleran, antikekerasan, dan menghargai perbedaan dan menghargai hak orang lain" (wawancara, 3/9/2013, Wahid, 2011, p.95) .

Selain hal tersebut, karena tasamuh dianggap sebagai salah satu sikap dapat menghargai perbedaan dan merangkul semua kalangan dari berbagai agama dan membangun harmoni dengan menjaga kerukunan antarumat beragama, maka para santri dan ustad Pesantren Tebuireng mempunyai keyakinan bahwa tasamuh merupakan salah satu akhlak karimah (wawancara, 3/9/2013). Lebih-lebih, ajaran tasamuh dan membangun harmoni diyakini merupakan salah satu substansi ajaran Islam yang harus dilestarikan dan perlu diajarkan melalui praktik nyata. Dalam tradisi Islam, kata al-tasamuh dan al-samhah sering diartikan dengan toleransi. Terdapat sebuah hadis yang menunjukkan komitmen Islam terhadap persolan toleransi ini yaitu: "Agama yang paling baik dicintai oleh Allah Swt adalah agama yang lurus dan toleran". Bahkan sebagaimana telah ditunjukkan oleh Zuhairi Misrawi (2010, pp.253-255), Kiai Hasyim meneguhkan komitmen tersebut secara eks- 
plisit di dalam mukadimah Qanun Asasi Nahdlatul Ulama.

Demi merealisasikan sikap tasamuh pada diri santri, kiai sebagai faktor kunci di pesantren perlu memberi keteladanan bagaimana dapat bersikap toleran kepada orang lain. Berdasarkan prinsip toleransi yang dipegang seperti itu, tak jarang Gus Solah, sebagaimana pengakuan sejumlah informan, melakukan kerja sama, berdialog, bahkan mengunjungi orang sakit meskipun dengan orang berbeda agama. Tentang persolan ini, Gus Solah menyatakan: "Yang beda ya tetap beda jangan disama-samakan. Meskipun kita yakin bahwa agama kita yang benar, tapi kita tidak punya hak untuk menyalah-yalahkan agama lain" (wawancara, 8/8/2012).

Selain itu, dalam proses belajar mengajarnya tidak boleh digunakan kekerasan. Di Pesantren Tebuireng, menurut penuturan Gus Solah, selalu ditanamkan pendidikan antikekerasan: "di sini diberikan sanksi yang cukup keras terhadap santri/siswa yang mela-kukan tindak kekerasan" (wawancara, 8/8/2013). Hal ini dengan sebuah pertimbangan bahwa prinsip toleransi (al-tasamuh) memastikan kehidupan yang damai dan rukun.

\section{Ukhuwah dan Solidaritas Kemanusiaan}

Kehidupan pesantren sebagai subkultur, memang menampakkan realitas yang berbeda dan unik bila dibanding dengan masyarakat di luarnya. Hubungan dan interaksi antara sesama, baik sesama santri maupun dengan orang lain, mencitrakan pola hubungan yang harmonis dan penuh persaudaraan. Bangunan konsep ukhuwah yang senantiasa diintrodusir oleh para kiai semenjak para santri pertama kali datang ke pesantren, mampu membekas pada benak setiap santri bahwa ia sebagai seorang muslim pada hakikatnya adalah bersaudara dengan muslim lainnya. Lebih-lebih dalam Islam ajaran ini merupakan Salah satu tema pokok yang diajarkan dalam Quran. Tentang persoalan ini, Fazlur Rahman menjelaskan bahwa sesungguhnya manusia adalah sebagai makhluk dualisme, yaitu sebagai makhluk individu dan masyarakat. Sebab tidak ada individu yang hidup tanpa masyarakat (Rahman, 1980: 54).

Beragam metode dan strategi yang telah digunakan para kiai pesantren untuk menyosialisasikan nilai ukhuwah sebagai salah satu variable penting dalam bangunan iman dan Islam, baik melalui transmisi secara langsung pada saat pengajian dan khutbah, dengan cara memberi anjuran dan wasiat dalam kitab-kitab kuning yang mereka tulis maupun melalui "percontohan". Sedangkan inti dasar dari ukhuwah yang dikembangkan pesantren adala menanamkan sikap kebersamaan dan mempererat tali persaudaraan di antara umat manusia. Jalinan persaudaraan yang dimaksud adalah bertujuan untuk menyatukan umat manusia dalam suatu kesatuan kebenaran dan keadilan yang bersifat menyeluruh, menggerakkan kesadaran santri dengan landasan sikap saling mengasihi dan menyayangi agar dapat menghormati dan menghargai satu sama lain, serta menciptakan perdamaian dalam masyarakat.

Dalam prespektif Pesantren Tebuireng dan pesantren kebanyakan, kata $u k h u$ wah terderivasi dari bahasa Arab "akhun" berarti saudara, sedangkan ukhuwah berbentuk mashdar mempunyai arti menjalin persaudaraan. Memperat sikap ukhuwah seperti ini merupakan perintah Islam. Nabi Muhammad pernah bersabda yang artinya: "Tidaklah beriman seseorang dari kamu sehingga dia mencintai saudaranya seperti dia mencintai dirinya sendiri". Kata akhihi, dalam hadis tersebut menurut Luthfi Taufiq, bukanlah sekedar keluarga se-ras, sebangsa/seagama melainkan umat manusia secara umum (Taufiq, 2012. p. 15).

Sedangkan menurut penjelasan Fatkhurrahman Karyadi, salah satu santri Tebuireng dan tercatat sebagai mahasiswa Ma'had Aly Hasyim Asy'ari, ukhuwah (persaudaraan) yang dimaksud dalam Islam mencakup tiga persaudaraan yaitu: pertama, ukhuwah basyariyah; maksudnya adalah persaudaraan kepada seluruh umat manusia di muka bumi. Sebuah simbol perdamaian dunia tanpa perbedaan. Kedua, ukhuwah Islamiyyah; sebuah persaudaraan sesama umat Islam lintas negara, madzhab dan aliran. Ketiga, ukhuwah wathaniy$y a h$; persaudaraan seluruh rakyat di suatu negara (Karyadi, 2012. p. 9).

Dengan begitu, sikap persaudaraan yang perlu direalisasikan Tebuireng sesungguhnya adalah mencakup pengertian yang komprehensif dan universal kepada seluruh umat manusia, tanpa sikap diskriminatif sedikit pun. Sebagai bentuk implementasi ajaran Islam yang memerintahkan hubungan kepada sesama manusia (hablum $\mathrm{min}$ al-nas), ter- 
masuk berhubungan antara muslim sendiri dan dengan penganut agama lain ini adalah sebuah akhlak Islami yang berdimensi sosial agar tercipta keterbukaan, saling menyapa dan persahabatan sesama umat manusia. Tentang persoalan ini, Kiai Hasyim sebenarnya telah memberikan percontohan tentang ide persatuan dan pentingnya mendahulukan sikap kelembutan dalam berdakwah sebagai terekam dalam pidato beliau pada Muktamar ketiga pada 1930 dengan judul Qanun Asasi Nahdhat al-Ulama'. Dalam pendahuluan pidato ini, selain mengajak pentingnya ajaran madzhab dan perlunya mengikuti ajaran ini beliau juga mengajak umat Islam untuk bersatu (ittihad); saling mengenal (ta'aruf); dan tenggang rasa (ta'aluf). Lebih lanjut pada Muktamar tahun 1936 di Banjarmasin, Kiai Hasyim juga menyerukan kaum muslimin terutama para Ulama untuk mengakiri pertikaian, perselisihan dan fanatisme golongan (ta'assub) demi menjaga persatuan umat (Khuluq, 2000, pp.113-114).

Sikap penting yang perlu diperhatikan dalam persoalan ukhuwah yang ditekankan oleh Kiai Hasyim adalah keikhlasan untuk merealisasikan cita-cita dan tujuan bersama, membangun kedamaian di muka bumi. Selain itu perlu kesamaan pandangan bahwa manusia memiliki perbedaan dan perbedaan bukan menjadi penghalang mengedepankan kerukunan dan keteraturan. Konsep ukhuwah seperti inilah yang mampu/diharapkan oleh Pesantren Tebuireng untuk mengantarkan setiap santri menjadi pribadi yang mempunyai sikap welas asih, toleran; dan peduli kepada sesama, meskipun ia berbasis pada latar belakang sosio-kultural yang berbeda dengan yang lain.

\section{Ta'awun dan Kepedulian Sosial}

Prinsip suka menolong dan berbuat baik kepada sesama senantiasa disosialisasikan dan diinternalisasikan pada Pesantren Tebuireng. Lebih-lebih Kiai Hasyim sebagai pendiri Pesantren Tebuireng juga sudah mengamanatkan dalam kitab Muqaddimah Qanun Asasi agar senantiasa menjaga sikap tolong-menolong sebagai berikut: "Saling menolonglah kalian dalam (mengerjakan) kebajikan dan takwa, dan jangan menolong dalam berbuat dosa dan bermusuhan. Dan bertakwalah kalian kepada Allah, sesungguhnya Allah sangat dahsyat siksa-Nya. Selain itu, Kiai Hasyim juga menegaskan bahwa sikap tolong menolong atau sikap saling membantu adalah pangkal keterlibatan umat Islam. Sebab, kalau tidak ada tolong menolong, niscaya semangat dan kemauan mereka akan lumpuh karena merasa tidak mampu mengejar cita-cita. Barang siapa mau tolongmenolong dalam persoalan dunia dan akhirat maka akan sempurnalah kebahagiaanya, nyaman dan sentosa hidupnya (Amin, 2009, p.15).

Semangat membantu dan wujud kepedulian kepada sosial telah direalisasikan oleh Semangat Tebuireng adalah dengan pembangunan Pusat Kesehatan Pesantren (Puskestren) berdiri pada tahun 1987-1988 dengan nama Unit Kesehatan Pesantren (UKP). Selain itu, juga pembentukan LSPT sebuah lembaga yang secara khusus bergerak di bidang penggalian dan pengelolaan dana, baik berupa zakat, infaq, shadaqah, waqaf, hibah, dan lain lain. Telah banyak program yang dicanangkan LSPT seperti: Banepas (Bantuan Abdi Pesantren), PSTM (Peduli Siswa Tidak Mampu), BeGe (Bagimu Guru), EmHa (Memmbangun Harapan) untuk bantuan anak-anak putus sekolah, PMM (Peduli Masyarakat Miskin) (Wawancara, 9/10/2013, Wahid, 2011: 175). Bahkan pada tahun 2013 ini, sebagaimana pernyataan Muhammad As'ad (Ketua LASPT) dengan melihat kenyataan banyak dari masyarakat miskin yang tidak mendapat Jamkesmas maka LSPT menerbitkan Kartu Tebuireng Sehat (KTS).

Program KTS ini akan di-launching saat pembukaan program pengobatan dan perawatan secara gratis, selain itu Tim Respons Cepat juga akan menindaklanjuti secara cepat terhadap masyarakat yang mendesak perlu bantuan. Sudah terdapat sekitar seratus orang pemegang KTS yang berasal dari masyarakat Tebuireng dan sekitarnya. Masyarakat yang sudah memegang KTS, dapat melakukan pemeriksaan, pengobatan, dan perawatan kesehatan di lembaga pelayananan kesehatan pondok. Jika diketahui warga mengalami sakit parah dan perlu penanganan serius, maka LSPT akan merujuknya ke rumah sakit dan biayanya di tanggung oleh LSPT (observasi dan wawancara, 25/08/2013).

\section{Jujur dan Ikhlas}

Melihat peran penting Jujur dan Ikhlas dalam membentuk kesempurnaan 
pribadi para generasi-generasi muslim, maka Pesantren Tebuireng mencoba mendesain terimplementasinya kedua karakter tersebut, di samping karakter yang lain seperti kerja keras, tanggung jawab dan tasamuh. Kelima nilai ini, sangat tampak akan dicoba untuk ditanamkan ke dalam diri santri. Sebagai strategi awal demi keberhasilan membentuk karakter positif dan sebagai nilai hasil warisan para leluhur tersebut, menurut Gus Fahmi (wawancara, 3/9/2013) adalah mencoba membangun kesadaraan bersama di antara seluruh komponen di Pesantren Tebuireng.

Ikhlas merupakan sesuatu yang bersifat intrinsik dan esensial bagi para nabi dan pewaris para nabi serta merupakan sumber kekuatan mereka. Ikhlas dapat ditafsirkan dengan kejujuran, ketulusan, dan kemurnian. Seseorang yang berhati ihklas dalam beramal dan beribadah, maka ia akan memiliki kemurnian niat, keterusterangan dalam pikiran, tidak mencari pamrih duniawi dalam hubungannya dengan Allah, dan taat dalam pengabdian kepada-Nya. Kiai Shalih Darat yang mempunyai nama lengkap Syekh Muhammad Shalih bin Umar al-Samarani, salah seorang guru Kiai Hasyim mendefinisikan arti ikhlas yaitu: "utawi anapun maknane lafaz ikhlas mangka iya iku barang ingkang murni kang ora kecampuran sawiji-wiji sangking barang liyo..." (Shalih, 1329, p.132). Sementara Jujur merupakan salah satu karakter dan sifat para nabi serta bukti ketakwaan dan keimanan mereka pada Zat yang menggengam seluruh alam beserta isinya ini.

Lebih-lebih sikap jujur dan ikhlas telah banyak ditemukan dalam karangan Kiai Hasyim yang telah memberikan percontohan sekaligus pesan pentingnya mentransmisikan sikap-sikap tersebut. Banyak riwayat yang menceritakan keikhlasan yang dicontohkan oleh Kiai Hasyim, di antaranya adalah bahwa beliau pernah menolak hadiah penghargaan berupa lencana emas dan perunggu pada tahun 1937 M, pemberian dari Pemerintahan Belanda, karena dianggap telah berjasa kepada masyarakat dan bangsa dengan kemajuan besar yang telah dihasilkan oleh Pesantren Tebuireng. Adapun alasan beliau menolak pemberian hadiah itu adalah karena khawatir tidak memperoleh pahala dari Allah dengan memperoleh perhatian manusia, dan konsisten memegang prinsip ikhlas serta menghindarkan dari perbuatan riya' (Wawancara, 13/10/2013).
Secara khusus Kiai Hasyim dalam kitab beliau Adab al-'Alim wal Muta'allim telah menjelaskan pentingnya kedua sikap tersebut demi terealisasinya tujuan dalam proses belajar mengajar. Seorang ulama harus mempunyai integritas keilmuan yang kuat dan harus dapat berkata jujur. Kiai Hasyim, menggambarkan karakteristik ulama dan hak-hak yang akan diberikan oleh Allah kepadanya jika memenuhi karakter sebagai ulama sebagai berikut:"...innama huwa fi haqqi al- 'ulamai al- 'amilina bi'ilmihim al-abrari al-muttaqina al-ladzina qasadu bihi wajha Allaha alkarima wa al-zulfa ladaihi bi jannati alna'imi, la man qashada bihi aghradlan dunyawiyatan min jahin au malin au mukatsaratin fi al-ittiba'i wa al-talamidzi..." (Asya'ari, tt: 22).

\section{Metode Sorogan dan Bandongan: Menjaga Identitas Santri}

Di tengah tarik menariknya antara tradisionalisme dan modernisme dalam pesantren, serta keinginan sebagian para kiai untuk memodernisasi pesantren dengan segala kelebihan dan kekurangannya. Pesantren Tebuireng masih lekat dengan karakter lokalitasnya untuk meneruskan tradisi belajar mengajar dengan sistem dan metode yang menurut Zuhairi Misrawi diinisiasi oleh Kiai Hasyim (Misrawi, 2010, p.66). Sistem pendidikan yang terkenal dengan sebutan "Sorogan dan Bandongan" pada realitasnya juga masih dipakai oleh sejumlah pesantren salaf di Indonesia. Salah satu alasan logis, masih dipertahankannya sistem pendidikan tradisional dengan pembelajaran kitab kuning adalah dalam rangka menjaga identitas para santri sebagai orang yang dipersiapkan secara khusus untuk menguasai ilmu-ilmu agama (tafaqquh fi al-din).

Begitu pula dengan Pesantren Tebuireng, di tengah geliat menuju pendidikan yang bermutu dan berkualitas serta mampu bersaing global/internasional, menurut pernyataan Ustad Su'udi, "Tebuireng tetap mempertahankan tradisi belajar mengajarnya dengan menggunakan kitab kuning dan metode sorogan dan bandongan (wawancara, 8/8/2012). Lebih kanjut, Ustad Jauhari membenarkan tentang sistem pendidikan yang masih berpijak pada kearifan lokal yang diajarkan oleh Kiai Hasyim. Bahkan menurutnya: "di sini, materi yang diajarkan pada santri dari dahulu sampai sekarang sama, yaitu terdiri dari ilmu- 
ilmu alat seperti nahwu/sharaf, tafsir, hadist, fiqih tauhid, dan tasawuf (wawancara, 9/8/2012).

Program pondok seperti muallimin dengan program takhassusnya senantiasa menjaga proses belajar mengajar dengan sistem sorogan/membaca sendiri. Sistem sorogan ini, berasal dari kata sorog (Jawa) yang berarti menyodorkan. Setiap santri menghadap dan menyodorkan kitabnya di hadapan kiai atau badalnya secara perorangan/sendiri-sendiri. Metode yang telah diperkenalkan oleh Kiai Idris dan menurut Gus Solah terinspirasi oleh pola pengajaran Imam Malik tersebut dilakukan secara mandiri/individual dan berkelanjutan serta menekankan inisiatif dan disiplin personal. Terbukti, model/metode pendidikan yang diterapkan Kiai Idris pada saat itu sangat berhasil. Sebab mampu memproduk kiai, atau minimal guru agama dan muballigh berpengaruh di masyarakat (Wahid, 2011, pp.35-36). Begitu kuatnya pengaruh metode sorogan dalam membentuk kualitas para santri, maka baru-baru ini metode yang sempat hilang ini digalakkan kembali di Tebuireng.

Selain itu, muallimin juga memakai cara weton. Weton berasal dari kata wektu (Jawa), sebab pengajian yang diberikan biasanya dilakukan pada waktu-waktu tertentu, yaitu sebelum atau sesudah melakukan shalat fardu. Sistem/metode weton di Jawa Barat terkenal dengan sebutan Bandongan. Metode ini biasanya menggunakan sistem kuliah. Para santri mengikuti pelajaran dengan duduk di sekeliling kiai yang menerangkan pelajaran secara kuliah. Santri menyimak kitab masingmasing dan membuat catatan padanya (Rahardjo, 1974: 87-88). Sistem pengajaran dengan sistem bandongan di Pesantren Tebuireng, terkenal dengan sebutan istilah wetonan. Sebenarnya metode ini tidak jauh berbeda dengan yang diterapkan oleh pondok-pondok lain pada umumnya. Setiap pagi, biasanya bertempat di masjid Pesantren Tebuireng dapat disaksikan metode pengajaran dengan sistem ini. Kiai dengan peralatan secukupnya seperti hanya dengan mikrofon membaca teks-teks klasik berbahasa Arab di hadapan para santri. Kalau kiai sedang capai atau sakit, biasanya dengan santai sambil duduk di atas kursi atau terkadang juga berbaring di atas kasur. Sementara para santri sambil duduk melingkari kiai terkadang di antara mereka yang bersandar di dinding-dinding masjid sambil memegang/memberi catatan-catatan pada kitab-kitab kuning. Mereka dengan kondisi yang serius dan tenang mendengarkan/ nampak tidak mau terlewatkan sedikit pun setiap kalimat demi kalimat yang dibacakan kiainya (Observasi, 9/10/2013).

Menurut beberapa santri, kitab yang dibaca/dibalah di Tebuireng setiap tahunnya tidak sama, karena membalah ini bukan ditunjuk oleh kiai, namun atas kemauan sendiri, hanya saja dapatnya kiai yang membalah suatu kitab disesuaikan dengan banyaknya santri yang berminat (wawancara, 9/10/2013). Ditambah lagi, sistem pengajaran dengan model sorogan dan wetonan di Tebuireng dilaksanakan secara bebas, dapat diikuti oleh semua santri tidak berdasarkan umur dan tingkatan, tetapi didasarkan pada kemampuan santri sendiri seperti Ula, Wustha dan Ulya. Selain itu, proses belajar mengajarnya tidak terikat secara ketat dengan aturan-aturan formal seperti adanya silabus yang terprogram dan absensi kehadiran.

\section{Mengkonstruk Identitas Santri Inklusif}

Globalisasi disadari atau tidak telah mendorong semua lembaga/masyarakat dan tidak ketinggalan adalah Pesantren Tebuireng untuk meningkatkan mutu dan kualitas SDM demi menjaga survivalitasnya, di samping juga menuntut mereka pada "kesadaran global" dan bisa berinteraksi satu sama lain. Sebab era ini sering diidentikkan dengan sebuah masa yang ditandai dengan proses informatisasi yang cepat karena kemajuan teknologi dan horizon kehidupan di planet ini semakin mengerut. Derasnya arus globalisasi yang datang dari Barat, sungguh telah menembus sekat-sekat kenegaraan. Semua yang hidup di bumi ini, tidak bisa terisolasi dengan realitas kebutuhan kepada orang dan masyarakat lain.

Melihat kenyataan perkembangan dunia tersebut, Pesantren Tebuireng dalam proses dinamika sejarahnya, sebagaimana telah disebutkan di atas, senantiasa menampilkan sikap inklusif untuk bisa menjemput globalisasi dengan tanpa merasa bermusuhan dengannya serta bisa mengakui dan menghormati kebudayaan/peradaban dari bangsa-bangsa lain, selama hal tersebut dirasa sangat bermanfaat bagi pengembangan Pesantren Tebuireng menuju pesantren yang bermutu, berkualitas, dan modern. Dalam bahasa Volume 3, Nomor 1,Juni 2015 
Ronald Lukens Bull (2004, p.14), kontruksi identitas yang ditampilkan Pesantren Tebuireng adalah masuk katagori "peacefull jihad" dalam menghadapi dan menyikapi persoalan globalisasi dengan senantiasa menyelaraskannya dengan nilai-nilai tradisional yang menjadi pegangan selama ini.

Selain itu, Pesantren Tebuireng tampak menyadari dan mengganggap proses pendidikan pada hakikatnya sebagai usaha sadar dan terencana untuk mengantarkan peserta didik agar bisa menjawab semua kebutuhan yang diperlukan pada masyarakat kontemporer. Sebuah masyarakat yang mensyaratkan adanya keterampilan (life skill) dan kesungguhan manusia-manusia yang menjadi pelakunya. Semua itu, bisa dibuktikan dengan reformulasi Pesantren Tebuireng sebagai sebuah lembaga yang telah memiliki visi dan misi yang berusaha mengantarkan para lulusanya agar menjadi bagian dan berkontribusi dari perkembangan globalisasi tersebut. Visi Pesantren Tebuireng adalah menjadi pesantren terkemuka penghasil insan pemimpin yang berakhlak dan misinya antara lain; membuat sistem manajemen pesantren dan sistem pendidikan pesantren yang berstandar international serta menjadi pusat pengkajian dan pengembangan pemikiran dan peradaban keislaman.

Semangat yang senantiasa diusung Pesantren Tebuireng hingga kini adalah memproduk santri berkarakter inklusif, mampu membaca zaman dan berakhlakul karimah. Santri Pesantren Tebuireng selain dituntut berkualitas/memiliki kompetensi (antara lain skill, knowledge, abality) dan harus mempunyai kesadaran yang tinggi untuk bersikap dan berperilaku sesuai moralitas/akhlak yang bersumber dari Islam dan budaya Indonesia. Kenyataan ini jika dianalisis dengan teori ekonomi, think globally act locally merupakan kenyataan yang bersifat urgen dan mendesak untuk dilakukan dalam menghadapi berbagai "konflik kepentingan" di pasar bebas. Menurut Robert F. Bruner (2004, pp.2-3), setiap orang yang memasuki pasar global, senantiasa harus mengikuti aturan permainan yang diatur oleh "sistem harga" yang terdapat di dalamnya dan dengan tetap memperhatikan sistem pasar lokal yang dimilikinya sendiri (Pieterse, 2004: 51).

Terdapat sejumlah budaya dan nilainilai luhur/kearifan lokal yang masih tetap dipertahankan di Pesantren Tebuireng sebagaimana telah disebutkan di atas. Semua kearifan itu, senantiasa ditransmisikan dan banyak dilakukan dengan berbagai strategi, baik melalui orally/ tall story (melalui budaya ngaji, khutbah, dan pitutur yang disampaikan kiai kepada santri/masyarakat ketika pada sowan atau melalui sambutan-sambutan pengajian), sejarah, dan nilai-nilai yang selalu diingat/dihapal melalui upacara keagamaan seperti haul, catatan/tulisan tentang kearifan lokal yang ditulis dalam kitab kuning, maupun melalui perayaan-perayaan keagamaan seperti idul fitri dan idul adha. Bahkan, bersamaan dengan semangat literasi yang ingin dibudayakan di Pesantren Tebuireng berbagai buku yang menceritakan tentang sejarah para sesepuh dan kiai-kiai dengan berbagai ajaran dan kearifannya telah dicetak secara khusus dan dengan mudah dibaca dan ditemui di sekitar pesantren. Semua itu, sekali lagi dalam rangka untuk memperkenalkan kepada seluruh santri dan masyarakat luas tentang sosok Mbah Hasyim yang telah banyak mengajarkan budaya dan nilai lokal khas pesantren dan terbukti compatible dengan nilai-nilai universal/globalisasi dengan semangat menjunjung tinggi watak keterbukaan dan saling menghargai sesama manusia dengan berbagai latar belakangnya.

Dalam prespektif historis, dalam menghadapi realitas globalisasi tersebut, Pesantren Tebuireng juga senantiasa hadir dalam panggung sejarah sebagai institusi yang responsif, proaktif, dan akomodatif dengan tuntutan masyarakat (society demand) yang beragam. Sejarah telah mencatat, bahwa pesantren yang pernah menjadi mahakarya KH. Hasyim Asy'ari ini, telah mencoba membawa modernisme ke jantung pesantren dengan memasukkan ilmu-ilmu sekuler ke dalam kurikulum pesantren. Sejak tahun 1900, Pesantren Tebuireng di bawah pengasuh Mbah Hasyim sendiri telah memiliki paradigma pendidikan non-dikotomik, dalam mensejajarkan ilmuilmu umum dan ilmu-ilmu agama, sehingga memungkinkan terjadinya integrasi dan sinkronisasi antara ilmu agama dan non-agama serta terjadi proses interaksi antara keduanya.

Ditambah lagi dengan melihat kenyataan sosiologis masyarakat yang majemuk, maka Solah satu bentuk akhlak karimah yang sangat ditekankan di Pesantren Tebuireng adalah tasamuh. Ini artinya, sebagai salah satu 
lembaga pendidikan agama, Pesantren Tebuireng telah ikut berperan aktif menyosialisasikan dan membangun perdamaian untuk saling menghormati dan mencintai sesama manusia. Lebih-lebih terdapat sejumlah kearifan lokal hasil peninggalan para kiai dan leluhur Pesantren Tebuireng yang menuntun dengan jelas karakter positif seperti mempraktikkan nilai-nilai multikulturalisme dan humanisme tersebut.

\section{SIMPULAN DAN SARAN}

Telah menjadi fakta dan kesadaran bersama bahwa Pesantren Tebuireng dengan paradigma dan filosofi al-muhafazhatu 'ala al-qadim al-shalih wa al-akhdzu bi al-jadid al-ashlah senantiasa berusaha menjadi penjaga tradisi yang bernilai baik dan menjadi pesantren yang terbuka terhadap sesuatu yang datang dari luar (modernitas) yang dinilai dapat bermanfaat bagi kemajuan Pesantren Tebuireng. Selain itu, dengan berlandaskan nilai tradisionalisme dan kearifan lokal hasil peninggalan Kiai Hasyim, Pesantren Tebuireng telah berupaya membentuk santri yang kuat secara akidah dan berakhlakul karimah sekaligus.

Pesantren Tebuireng juga senantiasa mengajarkan moderatisme dalam beragama dengan menunjukkan sikap keterbukaannya dengan pihak-pihak lain yang berbeda pandangan, menuntut para santri untuk mampu bekerjasama dan toleransi dengan pihak lain. Pesantren ini sangat menentang kerasa sikap ekstrimisme, fanatisme buta, dan sektearianisme dengan mengakui mazhabnya sendiri yang paling benar dengan menganggap remeh/salah pandangan orang lain. Sebab sikap-sikap seperti ini dianggap oleh Pesantren Tebuireng sangat mendukung terbentuknya perpecahan, perselisihan, dan perang saudara.

Adapun saran yang bisa direkomendasikan pada penelitian ini di antaranya adalah: (1) sebagai upaya merealisasikan paradigma “al-Muhafazhah”, Pesantren Tebuireng tampaknya perlu menunjukkan spesifikasi keilmuan yang telah menjadi kebesaran pesantren pada masa lampau, sehingga upaya al$a k h d z u$ yang dilakukan tidak terkesan lebih dominan dibanding menjaga tradisi lokalnya; (2) supaya lebih bisa meningkatkan inklusivitas keberagamaan, kepekaan, dan kepedulian sosial pada pribadi santri Pesantern
Tebuireng perlu memberikan pengalaman keberagamaan secara nyata pada para santri yunior, sebagaimana telah diprogramkan kepada para santri senior, termasuk untuk bisa berdialog dan ikut terlibat dalam persoalanpersoalan kemasyarakatan, menyelesaikan konflik agama, dan membantu korban bencana; (3) langkah penting yang perlu diterapkan Pesantren Tebuireng dalam rangka menyukseskan internalisasi nilai-nilai karakter yang sedang digalakkan adalah selain menyosialisasikan dan mengintegrasikannya dalam setiap kurikulum/mata pelajaran di setiap unit pendidikanya, Pesantren Tebuireng perlu meningkatkan/menggalakkan pada praksis sosial, sehingga nilai-nilai tersebut tidak terkesan menjadi simbol belaka. Tapi, benar-benar bisa terejawantah pada perilaku santri sehari-hari.

\section{DAFTAR PUSTAKA}

Amin, S. M. (2009). Karomah Para Kiai. Yogyakarta: LKiS.

Bruner, R.F. (2004). Think Globally Act Locally. Diakses pada tanggal 29 November 2013. Dari http://faculty. darden.virginia.edu/brunerb/Bruner $\mathrm{P}$ DF/Bruner_ThinkGlobally.pdf

Bull, R.L (2004). A Peacefull Jihad Javanese Islamic Education and Religious Identity Construction. (Terjemahan Abdurrahman Mas'ud, dkk). Yogyakarta: Gama Media.

Connolly, P. (Ed.) (2011). Aneka Pendekatan Studi Agama. Yogyakarta: LKiS.

Dhofier, Zamakhsyari. (1983). Tradisi Pesantren Studi tentang Pandangan Hidup. Kyai. Jakarta : LP3ES.

Fukuyama, F. (2007). The Great Disruption Human Nature and the Reconstitution of Social Order. (Terjemahan Ruslani). Jakarta: Qalam.

Huntington, S. P. (1993). The Clash of Civilization? Foreign Affairs, Summer.

Karyadi, F. (2012, September-Oktober). Silaturrahim dan Ukhuwwah. Majalah Tebuireng, 23, 7-9.

Khuluq, L. (2000). Fajar Kebangunan Ulama Biografi K.H. Hasyim Asy'ari. Yogyakarta: LKiS. 
Knight, G.R. (1982). Issues and Alternatives in Educational Philosophy, Michigan: Andrews University Press.

Misrawi, Z. (2010). Hadratussyaikh Hayim Asy'ari Moderasi, Kemuatan, dan Kebangsaan. Jakarta: Kompas Penerbit Buku.

Moleong, L.J. (2007). Metodologi Penelitian Kualitatif. Bandung: PT Remaja Rosdakarya.

Muhadjir, N. (2011). Filsafat Ilmu. Yogyakarta: Rake Sarasin.

Pieterse, J.N. (2004). Globalization and Culture Global Melange. USA: Rowman \& Littlefield Publisher, Inc.

Rahardjo, M.D. (1974). Pesantren dan Pembaharuan. Jakarta: LP3S.

Rahman, F. (1980). Islam And Modernity. Chicago:The University of Chicago Press.

Shalih, M. (1329). Munjizat. Semarang: t.p.

Spradley, J.P. (1997). The Etnograpihc Interview. (Terjemahan Misbah Zulfa Elizabeth). Yogyakarta: Tiara Wacana.
Taufiq, L. (2012, September-Oktober). Ukhuwwah Basyariyah sebagai Silaturrahim Level Tertinggi. Majalah Tebuireng, 23, 14-15.

Travers, M. (2001). Qualitative Research Through Case Studies. London: SAGE Publications Ltd.

Wahid, A. (2007). Islam Kosmopolitan: NilaiNilai Indonesia dan Transformasi Kebudayaan. Jakarta: The Wahid Institute.

Wahid, S. (2011). Transformasi Pesantren Tebuireng Menjaga Tradisi di Tengah Tantangan, Malang: UIN-Maliki Press.

Wahid, S. (2014, Juni 20). Sulitnya Mencapai Kata Sepakat. Jawa Pos, p. 4.

Wahid, S. (2012, September-Oktober). Memperluas Makna Silaturrahim. Majalah Tebuireng, 23, 5-6.

Yasin, A. M. Dan Karyadi, F. (Ed.). (2011). Profil Pesantren Tebuireng. Jombang: Pustaka Tebuireng.

Ziemek, M. (1986). Pesantren dan Perubahan Sosial. (Terjemahan Butche Soendjojo). Jakarta: P3M. 